\title{
Gebruikersonderzoek HBO-monitor
}

Citation for published version (APA):

de Beer, M. E. E., \& Ramaekers, G. W. M. (2001). Gebruikersonderzoek HBO-monitor. Researchcentrum voor Onderwijs en Arbeidsmarkt, Faculteit der Economische Wetenschappen. ROA Working Papers No. 1 https://doi.org/10.26481/umarow.2001001

Document status and date:

Published: 01/01/2001

DOI:

10.26481/umarow.2001001

Document Version:

Publisher's PDF, also known as Version of record

\section{Please check the document version of this publication:}

- A submitted manuscript is the version of the article upon submission and before peer-review. There can be important differences between the submitted version and the official published version of record.

People interested in the research are advised to contact the author for the final version of the publication, or visit the DOI to the publisher's website.

- The final author version and the galley proof are versions of the publication after peer review.

- The final published version features the final layout of the paper including the volume, issue and page numbers.

Link to publication

\footnotetext{
General rights rights.

- You may freely distribute the URL identifying the publication in the public portal. please follow below link for the End User Agreement:

www.umlib.nl/taverne-license

Take down policy

If you believe that this document breaches copyright please contact us at:

repository@maastrichtuniversity.nl

providing details and we will investigate your claim.
}

Copyright and moral rights for the publications made accessible in the public portal are retained by the authors and/or other copyright owners and it is a condition of accessing publications that users recognise and abide by the legal requirements associated with these

- Users may download and print one copy of any publication from the public portal for the purpose of private study or research.

- You may not further distribute the material or use it for any profit-making activity or commercial gain

If the publication is distributed under the terms of Article $25 \mathrm{fa}$ of the Dutch Copyright Act, indicated by the "Taverne" license above, 


\title{
Gebruikersonderzoek HBO-Monitor
}

\author{
ROA-W-2001/1 \\ M.E.E. de Beer en G.W.M. Ramaekers
}

Researchcentrum voor Onderwijs en Arbeidsmarkt

Faculteit der Economische Wetenschappen en Bedrijfskunde Universiteit Maastricht

Maastricht, januari 2001 
ISBN 90-5321-303-1

Sec01.025.doc 


\section{Inhoud}

Voorwoord

Samenvatting

1 Inleiding

2 Gebruikersonderzoek HBO-Monitor 2

2.1 Probleemstelling 2

2.2 Onderzoeksopzet 3

3 Onderzoeksresultaten landelijk rapportage 4

3.1 Onderzoeksvragen 4

3.2 Gebruikers $\quad 5$

3.3 Gebruiksdoelen $\quad 7$

3.4 Gebruikswaarde 8

3.5 Gebruikersbehoeften 11

3.6 Gebruikersoordeel 12

4 Onderzoeksresultaten instellingsrapportages 14

4.1 Onderzoeksvragen 14

4.2 Gebruikers 14

4.3 Gebruiksdoelen en bruikbaarheid $\quad 16$

$\begin{array}{lr}4.4 \text { Waardering onderdelen instellingsrapportage } & 17\end{array}$

4.5 Gebruikersbehoeften 18

4.6 Gebruikersoordeel 19

5 Systematische evaluatie $\quad 21$

$\begin{array}{ll}5.1 \text { Huidige opzet } & 21\end{array}$

5.2 Nieuwe opzet 21

6 Conclusie 22

Bijlage 1 Vragenlijst landelijk rapport 25

Bijlage 2 Vragenlijst instellingsrapportages 29 



\section{Voorwoord}

Dit werkdocument is een verslag van het gebruikersonderzoek dat najaar 2000 door het Researchcentrum voor Onderwijs en Arbeidsmarkt (ROA) is uitgevoerd onder de afnemers van de jaarlijkse rapportages van de HBO-Monitor. Het onderzoek naar het gebruik van de HBO-Monitor werd door mij uitgevoerd in het kader van mijn oriënterende stage voor het HEAO te Sittard.

Vanaf begin jaren negentig heeft het ROA een hoofdrol gespeeld in het Nederlandse onderzoek naar de transitie van school naar werk. Destijds werd geconstateerd dat systematische informatie met betrekking tot deze transitie grotendeels ontbrak. Het ROA heeft zich toen tot taak gesteld het systematisch monitoren van schoolverlaters en afgestudeerden te bevorderen. Via een breed ontwikkeld instrumentarium is het mogelijk gebleken jaarlijks een beeld te schetsen van de arbeidsmarktpositie van nieuwkomers. Daarbij is uitdrukkelijk gezocht naar afstemming van het onderzoek op het stelsel van kwaliteitszorg dat door de onderwijsinstellingen zelf is ontwikkeld. Hierdoor is het draagvlak van het onderzoek aanmerkelijk vergroot. De verschillende schoolverlatersonderzoeken omvatten inmiddels de gediplomeerde uitstroom van het gehele onderwijssysteem van schoolverlaters van het voortgezet onderwijs tot en met afgestudeerden van het wetenschappelijk onderwijs.

De HBO-Monitor richt zich door middel van de enquêtering van HBO-afgestudeerden op het vergroten van de inzichtelijkheid van de transitie van het hoger beroepsonderwijs naar de arbeidsmarkt. Naar aanleiding van het tienjarig bestaan van de HBO-Monitor is mij gevraagd hiervoor een gebruikersonderzoek uit te voeren. Ondanks het feit dat marketing niet centraal staat in mijn studie heb ik met veel genoegen aan het onderzoek gewerkt. Het feit dat het onderzoek eigen verantwoordelijkheid, inzicht maar ook creativiteit vereist sprak mij bijzonder aan. Daarnaast sloot het aan bij de klantgerichte benadering die in steeds meer organisaties (ook niet-commerciële) een belangrijkere rol gaat spelen. Want ook voor een onderzoeksinstituut als het ROA is het van groot belang dat er informatie wordt verzameld over de gebruikswaarde van de onderzoeken teneinde de kwaliteit alsmede de bruikbaarheid van de onderzoeksrapporten, waaronder de HBO-Monitor, te kunnen waarborgen. Met dit werkdocument hoop ik een relevante bijdrage te kunnen leveren aan de kwaliteitszorg voor de rapportages van de HBO-Monitor.

De uitvoering van dit gebruikersonderzoek HBO-Monitor is mogelijk gemaakt dankzij de medewerking van mijn collega's op het ROA waarbij ik Ger Ramaekers in het bijzonder bedank voor zijn stagebegeleiding. Daarnaast dank ik ook Felipe Salve van de HBO-raad, Monique van Alphen van DESAN marktonderzoek en mijn stagedocent Dor van Bilsen voor hun aanbevelingen. Tenslotte ben ik ook dank verschuldigd aan diegene die meegewerkt hebben aan het onderzoek, namelijk de geënquêteerden.

Maastricht, 15 december 2000

M.E.E. de Beer 


\section{Samenvatting}

De aanleiding voor het gebruikersonderzoek is de behoefte aan inzicht bij de opstellers van de HBO-Monitor met betrekking tot de gebruikersgroepen, gebruiksdoeleinden, mate van bruikbaarheid en specifieke gebruikersbehoeften.

De vragenlijsten van het gebruikersonderzoek zijn verstuurd naar 218 afnemers van de landelijke rapportage en 111 afnemers van de instellingsrapportages, die in het kader van de HBO-Monitor 1999 zijn opgesteld. De adressenbestanden zijn ter beschikking gesteld door de HBO-raad en DESAN marktonderzoek. Het onderzoek resulteerde in een respons van $33 \%$ voor de landelijke rapportage en $36 \%$ respons voor het onderzoek ten behoeve van de instellingsrapportages.

\section{Landelijke rapportage}

De landelijke rapportage bestaat uit een rapport met bijbehorend statistisch supplement. De hogescholen vormen de grootste groep gebruikers van de landelijke rapportage. Zij gebruiken zowel het rapport als het statistisch supplement het meest voor algemene kennisneming van de arbeidsmarktpositie van hbo'ers, in het kader van de kwaliteitszorg, het onderwijsbeleid, studie- en beroepskeuzevoorlichting, alsmede voor eigen onderzoek. De bruikbaarheid van zowel het rapport als het statistisch supplement voor deze doeleinden wordt als redelijk tot goed gekwalificeerd.

Met betrekking tot het rapport geven de gebruikers aan dat dit zowel beschrijvend als analytisch van aard moet zijn. Ten aanzien van het statistisch supplement geeft de meerderheid van de gebruikers te kennen dat de gepresenteerde informatie niet hoeft te worden gewijzigd: er hoeft geen informatie te worden toegevoegd (aangezien de meeste gebruikers geen informatie missen) noch geschrapt (aangezien de meeste gebruikers vinden dat het statistisch supplement geen overbodige informatie bevat). Wel vindt de meerderheid dat in de tabellen van het statistisch supplement de totaalcijfers voor het HBO moeten worden gesplitst in HBO-voltijd en HBO-deeltijd. Het statistisch supplement dient volgens de meeste gebruikers zowel op papier als op diskette beschikbaar te komen. Overigens zijn de gebruikers overwegend positief over het geautomatiseerd statistisch supplement, met een gemiddeld rapportcijfer van 6,9 voor zowel de gebruiksvriendelijkheid als de overzichtelijkheid.

Alles overziend, zijn de gebruikers redelijk tot goed te spreken over het nut $(7,4)$ de betrouwbaarheid $(7,0)$ en de prijs-kwaliteitverhouding $(6,6)$ van de landelijke rapportage HBO-Monitor.

\section{Instellingsrapportages}

De instellingsrapportages worden het vaakst gebruikt door kwaliteitszorgmanagers, faculteitsdirecties, opleidingscoördinatoren en bestuurders op centraal niveau van hogescholen. De rapportages worden vooral gebruikt voor het monitoren van het extern rende- 
ment, evaluatie van het curriculum en voorlichting. De bruikbaarheid voor deze doeleinden wordt als ruim voldoende gekwalificeerd. Volgens de meerderheid van de gebruikers hoeven de instellingsrapportages, wat de opgenomen informatie betreft, niet te worden gewijzigd: enerzijds hoeft geen informatie te worden toegevoegd (aangezien de meeste gebruikers geen informatie missen) en anderzijds hoeft geen informatie te worden geschrapt (aangezien de instellingsrapportages volgens de meeste gebruikers geen overbodige informatie bevatten). Desgevraagd, antwoordt de meerderheid van de gebruikers dat het niet nodig is om de managementrapportage als afzonderlijk rapport aan te bieden.

De overgrote meerderheid van de gebruikers vindt het aanbod om deel te nemen aan de HBO-Monitor volledig én duidelijk, ook wat de mogelijkheid tot het opnemen van instellingsspecifieke vragen betreft. Er lijkt dus wat dit betreft geen aanleiding te zijn om het aanbod bij te stellen. Wellicht is het wenselijk om de mogelijkheid voor een follow-up meting expliciet onder de aandacht van hogescholen te brengen, aangezien een kwart tot een derde van de onderzochte hogescholen behoefte heeft aan een follow-up meting onder afgestudeerden.

De betrouwbaarheid en prijs-kwaliteitverhouding van de HBO-Monitor worden met een gemiddeld rapportcijfer van respectievelijk 7,1 en 6,7 als (ruim) voldoende gekwalificeerd. Tenslotte blijkt dat driekwart van de respondenten wil deelnemen in een digitaal discussieforum om zo gestalte te geven aan een periodieke evaluatie van de HBO-Monitor. Volgens de respondenten is een dergelijk digitaal discussieforum, in samenhang met een klankbordgroep voor de HBO-Monitor, afdoende om een structurele input van hogescholen bij de HBO-Monitor te waarborgen. 


\section{Inleiding}

Het Researchcentrum voor Onderwijs en Arbeidsmarkt (ROA) heeft als doelstelling te zorgen voor een wetenschappelijke bijdrage aan het inzichtelijk maken van de aansluiting onderwijs-arbeidsmarkt voor belanghebbenden. Een belangrijk instrument om deze bijdrage te leveren is het informatiesysteem Onderwijs-Arbeidsmarkt. Dit systeem verschaft gegevens over de huidige en toekomstige positie van opleidingen op de arbeidsmarkt. De huidige aansluiting tussen het onderwijs en de arbeidsmarkt wordt met name in kaart gebracht door het jaarlijks enquêteren van schoolverlaters en afgestudeerden op verschillende opleidingsniveaus. Op HBO-niveau gebeurt dit met behulp van de HBO-Monitor. Begin jaren negentig is dit onderzoeksinstrument opgezet, hiermee kunnen hogescholen ieder jaar de arbeidsmarktpositie van hun afgestudeerden in kaart laten brengen. Zo kunnen ze zien in hoeverre de opleidingen aansluiten op de arbeidsmarkt en de beroepspraktijk, een belangrijk thema in het debat over de kwaliteit en het extern rendement van het HBO. Daarnaast geeft de HBOMonitor inzicht in het oordeel van afgestudeerden over verschillende aspecten van het onderwijs. Alle HBO-sectoren zijn in de monitor vertegenwoordigd. Voor de kunstensector is een eigen Kunsten-Monitor en voor het hoger pedagogisch onderwijs is een eigen Onderwijs-Monitor ontwikkeld. In 1999 zijn in totaal circa 38.600 afgestudeerde hbo'ers van examenjaar 1997/1998 benaderd om mee te doen aan de HBO-Monitor.

In het kader van het tienjarig bestaan van de HBO-Monitor is door het ROA en de HBO-raad besloten tot het uitvoeren van een gebruikersonderzoek. Het onderzoek richt zich met name op de analyse van de gebruiksdoeleinden en gebruikswaarden van de HBO-monitor voor de verschillende belanghebbenden. Gedurende het tienjarig bestaan van de HBO-monitor, die in opdracht van de HBO-raad uitgevoerd wordt door het ROA in samenwerking met DESAN marktonderzoek, heeft er tot nu toe geen systematische gebruikersevaluatie plaatsgevonden. Met dit werkdocument wordt de eerste aanzet gegeven om te komen tot een structurele gebruikersevaluatie. Deze gebruikersevaluatie moet resulteren in bruikbare feedback om de jaarlijks uit te brengen HBO-Monitor te verbeteren. De rapportages HBOMonitor bestaan uit een openbaar landelijk rapport inclusief een statistisch supplement (landelijke rapportage HBO-Monitor) en vertrouwelijke instellingsrapportages voor de afzonderlijke deelnemende HBO-instellingen. Het uitgevoerde gebruikersonderzoek valt eveneens uiteen in twee delen. Zo richt het onderzoek zich op de evaluatie van de gebruiksdoelen en de gebruikerswaarden van zowel de landelijke rapportage als de vertrouwelijke instellingsrapportages.

In hoofdstuk 2 van dit werkdocument wordt een algemene beschrijving gegeven van het uitgevoerde gebruikersonderzoek. Daarbij wordt aandacht besteed aan de probleemstelling en de onderzoeksopzet. In hoofdstuk 3 van dit rapport worden de onderzoeksresultaten behandeld van het gebruikersonderzoek ten behoeve van het landelijk rapport en het statistisch supplement. Paragraaf 3.1 behandelt de onderzoeksvragen, waarna paragraaf 3.2 een beschrijving geeft van de gebruikers. De daaropvolgende paragrafen gaan over de gebruiksdoelen, de gebruikswaarde, de gebruikersbehoeften en het gebruikersoordeel voor de landelijke rapportage HBO-Monitor. In hoofdstuk 4 worden resultaten gepresenteerd van het gebruikersonderzoek ten behoeve van de instellingsrapportages. Paragraaf 4.1 gaat in 
op de geformuleerde onderzoeksvragen. In de daaropvolgende paragrafen staan de gebruikers, de gebruiksdoeleinden en gebruikswaarden, de waardering voor de instellingsrapportage, de gebruikersbehoeften en het gebruikersoordeel centraal. Hoofdstuk 5 staat stil bij het model voor systematische evaluatie en de oprichting van een klankbordgroep en een digitaal discussieforum. Het werkdocument wordt afgesloten met een korte samenvatting en een conclusie.

\section{Gebruikersonderzoek HBO-Monitor}

\subsection{Probleemstelling}

De probleemstelling die ten grondslag ligt aan dit gebruikersonderzoek, is de behoefte aan inzicht bij de opstellers van de HBO-Monitor met betrekking tot:

- de aard en omvang van de gebruikersgroepen;

- de aard en omvang van de gebruiksdoelen;

- de mate van bruikbaarheid;

- specifieke gebruikersbehoeften.

De vraag is dus wie de gebruikers zijn, welk gebruik de afnemers van de informatie maken en in welke mate de rapportages voorzien in hun informatiebehoeften. Zijn zij tevreden over de opzet, de inhoud en presentatie van de landelijke rapportage, het bijbehorend statistisch supplement en de instellingsrapportages?

Dit gebruikersonderzoek moet de aanzet geven tot een eerste systematische evaluatie waarbij onder andere zal worden gekeken of de gebruiksmogelijkheden van de HBO-Monitor wel ten volle worden benut. De gebruiksmogelijkheden zijn immers zeer uitgebreid. Zo kan de informatie uit de landelijke rapportage worden aangewend voor:

- algemene kennisneming van de arbeidsmarktpositie van HBO'ers;

- studie- en beroepskeuzevoorlichting;

- kwaliteitszorgbeleid;

- voorlichting;

- onderzoek.

De gebruiksmogelijkheden van de instellingsrapportages zijn evenals de landelijke rapportage uitgebreid te noemen. Zo kan de informatie uit de instellingsrapportages onder andere worden aangewend voor de volgende doeleinden.

- Kwaliteitszorgbeleid: hogescholen en faculteiten kunnen de instellingsrapportage gebruiken voor het monitoren van het extern rendement. Dat houdt in dat er een beeld wordt geschetst van de arbeidsmarktperformance van hun afgestudeerden. Dit kan aanleiding zijn om het curriculum aan te passen om zo de aansluiting met de beroepsloopbaan zo soepel mogelijk te laten verlopen.

- PR en voorlichting: de instellingsrapportage stelt de hogeschool/faculteit in de gelegenheid om objectieve cijfers te presenteren over de arbeidsmarktperformance van hun afgestudeerden. Een handig middel voor zowel interne als externe voorlichting. 
- Alumnibeleid: het alumnibeleid richt zich op het onderhouden van contacten met afgestudeerden. De hogeschool/faculteit wordt door de individuele rapportage in staat gesteld om bijvoorbeeld bedrijvencontactdagen en terugkomdagen te organiseren en loopbaanadvies te verstrekken aan studenten c.q. afgestudeerden.

Het ontbreken van feedback bij de opstellers van de rapportages blijkt een probleem te zijn om het gebruik van het landelijk rapport (en het statistisch supplement) alsmede van de instellingsrapportages te kunnen inschatten. Het gebruikersonderzoek sluit daarmee aan bij het instrumenteel onderzoek teneinde de kwaliteit van de verzamelde gegevens te verbeteren. Het is belangrijk om bestaande projecten waaronder de HBO-Monitor te evalueren en zonodig te vernieuwen. De huidige opzet van de HBO-Monitor wordt gekenmerkt door relatief eenzijdige informatiestromen. De opstellers rapporteren hun bevindingen in de landelijke rapportage en de instellingsrapportages zonder dat daarbij een periodieke systematische terugkoppeling plaatsvindt.

\subsection{Onderzoeksopzet}

De uitvoering van het onderzoek geschiedde door middel van een schriftelijke enquête, verspreid onder 218 gebruikers van de landelijke rapportage en 111 gebruikers van instellingsrapportages binnen hogescholen/faculteiten die deelnemen aan de HBO-Monitor. In de vragenlijsten werden de centrale onderzoeksvragen verder uitgewerkt naar items die ingaan op enkele praktische en actuele aandachtspunten. Aan het eind van dit werkdocument is de vragenlijst voor het gebruikersonderzoek van de landelijke rapportage als bijlage 1 en die van de instellingsrapportage als bijlage 2 opgenomen. Bij het opstellen van het enquêteformulier is in eerste instantie de vragenlijst van een reeds eerder uitgevoerd gebruikersonderzoek als uitgangpunt genomen. Desbetreffend onderzoek richtte zich op het ROA-rapport: De arbeidsmarkt naar opleiding en beroep tot 2000. De lijst is echter sterk aangepast aan de gebruikers en de gebruiksmogelijkheden van de HBO-Monitor. Uiteraard zullen bij de beoordeling van de onderzoeksresultaten de centrale onderzoeksvragen als leidraad fungeren.

Beide vragenlijsten zijn eerst voor commentaar voorgelegd aan verschillende medewerkers binnen de afdeling Onderwijs en Beroepsloopbaan van het ROA die direct of indirect betrokken zijn bij de opstelling van de HBO-Monitor. De vragenlijsten zijn daarnaast voor commentaar voorgelegd aan de HBO-raad en DESAN. De HBO-raad heeft zorg gedragen voor de verzending van de vragenlijsten ten behoeve van het landelijk rapport en het statistisch supplement. Naast de vragenlijst hebben de geënquêteerden een begeleidend schrijven van de HBO-raad en een portovrije retourenveloppe met antwoordnummer ontvangen. De lijst van potentiële respondenten is bepaald op basis van het adressenbestand van de HBO-raad. Het betrof de afnemers van de landelijke rapportage 1999. De verzending van de vragenlijsten voor de evaluatie van de instellingsrapportage heeft het ROA zelf verzorgd. De adressen van de verschillende deelnemende hogescholen/faculteiten zijn ter beschikking gesteld door DESAN marktonderzoek te Amsterdam. Ook bij deze verzending waren de vragenlijsten voorzien van een aanbiedingsbrief en een portovrije retourenveloppe met antwoordnummer. 
Het onderzoek met betrekking tot de evaluatie van de landelijke rapportage heeft als eerste plaatsgevonden. Gezien het feit dat er geen duidelijk inzicht bestond in de aard van de gebruiker is eerst gevraagd welk soort organisatie de respondent vertegenwoordigde. Ook is gevraagd naar de wijze van kennisneming over het bestaan van de HBO-Monitor. Deze informatie zou belangrijk kunnen zijn om het landelijk rapport in de toekomst gerichter onder de aandacht te brengen. Daarnaast is achtereenvolgens gevraagd naar de gebruiksdoelen van de landelijke rapportage HBO-Monitor, de mate van bruikbaarheid van de landelijke rapportage voor betreffende gebruiksdoelen, en de specifieke gebruikersbehoeften.

Het gebruikersonderzoek ten behoeve van de instellingsrapportages ging enkele weken later van start. Zoals gezegd was de groep potentiële respondenten een stuk kleiner. De vragenlijst (zie bijlage 2) behandelt de verschillende aspecten die een rol spelen bij de opstelling en het gebruik van de instellingsrapportage. Zo is gevraagd naar algemene informatie, zoals de status van de respondent, een oordeel met betrekking tot de dataverzameling, de structuur, de inhoud alsmede de gebruikswaarde van de rapportage. Deze gebruikswaarde is uitgesplitst naar de verschillende onderdelen van de rapportage, te weten het managementrapport, het statistisch overzicht, de individuele rapportage, de technische toelichting en het toekomstperspectief. Daarbij is een oordeel gevraagd met betrekking tot de bruikbaarheid, overzichtelijkheid en volledigheid. Tenslotte is in de vragenlijst een oordeel gevraagd over een op te richten digitaal discussieforum. Daarbij kon de respondent tevens aangeven of hij wilde participeren in het digitaal discussieforum.

\section{Onderzoeksresultaten landelijk rapportage}

\subsection{Onderzoeksvragen}

In dit hoofdstuk zal aan de hand van de in paragraaf 2.1 geformuleerde probleemstelling ingegaan worden op de onderzoeksvragen met betrekking tot het landelijk rapport. Het gaat om de volgende onderzoeksvragen.

- Wat is de aard van de organisaties die het rapport en de bijbehorende statistische bijlage hebben besteld of gekregen?

- Waarvoor gebruikt men het rapport en de bijbehorende statistische bijlage?

- Welke waardering geeft men aan de gebruikswaarde van het rapport en de bijbehorende statistische bijlage?

- Bestaat er bij de verschillende gebruikersgroepen behoefte aan uitbreiding van de gepresenteerde informatie?

- Wat is de waardering van de gebruikersgroepen met betrekking tot de gebruiksvriendelijkheid en de overzichtelijkheid van het geautomatiseerd statistisch supplement?

- Wat is het eindoordeel van de verschillende gebruikersgroepen met betrekking tot het nut, de betrouwbaarheid en de prijs-kwaliteitverhouding van de publicatie? 
Daarnaast is gevraagd naar de volgende specifieke aspecten.

- Op welke wijze heeft de gebruiker kennisgenomen van het bestaan van de HBOMonitor?

- Wat is het meest gebruikte onderdeel van de publicatie?

- Waarom maken sommige geënquêteerden geen gebruik van bepaalde onderdelen van de publicatie?

- In welke mate is er sprake van overbodig gepresenteerde informatie?

- In welke vorm dient het statistisch supplement in de toekomst beschikbaar te komen?

\subsection{Gebruikers}

Zoals in paragraaf 2.1 al is betoogd, dient het landelijk rapport inclusief het bijbehorend statistisch supplement verschillende gebruiksdoelen en daarmee verschillende gebruikers. Derhalve zijn de vragenlijsten verspreid onder alle afnemers die zijn opgenomen in de verzendlijst van de HBO-raad. In totaal zijn 218 personen aangeschreven die werkzaam zijn bij hogescholen, onderzoeksinstellingen, overheden etc. De grootste groep geënquêteerden vormden de hogescholen met een totaal van 159 personen, ofwel 73\% van de onderzoekspopulatie. In tabel 1 is dan ook te zien dat de hogescholen met $89 \%$ het merendeel van de respondenten vertegenwoordigen. Het is dus van belang om rekening te houden met het grote gewicht dat de hogescholen hebben in de onderzoeksresultaten. Zo zouden zij bijvoorbeeld het gebruik en de bruikbaarheid van de HBO-Monitor afwijkend kunnen beoordelen. Het feit dat de hogescholen het meest betrokken zijn bij de uitvoering van de $\mathrm{HBO}-M o n i t o r$ en zij tevens vaste afnemers zijn van de rapportages kan verklaren waarom hogescholen licht zijn oververtegenwoordigd in de steekproef.

Tabel 1

Respons naar soort organisatie

Hogeschool

Onderzoeksinstelling

Andere onderwijsinstelling

Rijksoverheid

$1 \%$

Commercieel bedrijf

$1 \%$

Overig

$1 \%$

Totaal $n(=100 \%)$

71

Daarnaast kan worden opgemerkt dat het totaal aantal respondenten 71 personen is, hetgeen neerkomt op een respons van 33\% (ter vergelijking: bij een eerder verricht gebruikersonderzoek betreffende het rapport De arbeidsmarkt naar opleiding en beroep tot 2000 bedroeg de respons 26\%). Dit wil echter niet zeggen dat alle in de tabellen gepresenteerde percentages en scores steeds gebaseerd zijn op de antwoorden van 71 respondenten. Het kan namelijk voorkomen dat geënquêteerden bepaalde vragen openlaten, bijvoorbeeld omdat de desbetreffende vraag voor hen niet van toepassing is. De 
percentages en scores zijn derhalve steeds gebaseerd op het totaal aantal gegeven antwoorden. Ook kan het zijn dat op een enkele vraag meerdere antwoorden mogelijk zijn. De gepresenteerde percentages tellen daardoor niet altijd op tot 100 procent maar vertegenwoordigen het relatief aantal antwoorden op de betreffende vraag. Vanwege het feit dat van de 71 respondenten 63 respondenten bij een hogeschool werkzaam zijn en slechts 8 respondenten bij een ander soort instelling, wordt in de tabellen geen onderscheid gemaakt tussen hogescholen en overige gebruikers. Wel zal in de tekst steeds worden vermeld wanneer een verschil tussen hogescholen enerzijds en overige gebruikers anderzijds statistisch significant is op tenminste $10 \%$-niveau.

In tabel 2 wordt aangegeven op welke wijze de gebruikers kennis hebben genomen van het bestaan van het rapport $H B O-M o n i t o r$ De arbeidsmarktpositie van afgestudeerden van het hoger beroepsonderwijs 1999 en het bijbehorend statistisch supplement. Uit de tabel blijkt duidelijk dat de meeste gebruikers van het bestaan van het rapport hebben kennisgenomen via eerdere rapportages van de HBO-Monitor of omdat zij de rapportage direct hebben ontvangen van de HBO-raad (van de niet-hogescholen heeft niemand het rapport ontvangen via directe toezending door de HBO-raad). De kennisneming via media scoort zeer laag. $\mathrm{Er}$ kan derhalve worden verondersteld dat de afnemers van de HBO-Monitor een relatief vaste groep van instellingen zijn.

Tabel 2

Wijze van kennisneming*

Via eerdere rapportages HBO-Monitor

Bericht in tijdschrift/krant

* meerdere antwoorden mogelijk

Zoals eerder is gezegd, bestaat de landelijke publicatie HBO-Monitor uit een rapport en bijbehorend statistisch supplement. Circa een vijfde (18\%) van de respondenten gebruikt voornamelijk het rapport, terwijl $12 \%$ voornamelijk het statistisch supplement gebruikt. Het merendeel van de respondenten (71\%) geeft echter aan dat zij zowel het landelijk rapport als het statistisch supplement in hun organisatie gebruiken. Dit statistisch supplement is het afgelopen jaar alleen nog beschikbaar gekomen in geautomatiseerde vorm. In de vragenlijst is hierop ingespeeld door middel van enkele vragen met betrekking tot de wenselijkheid van dit geautomatiseerd supplement. Zo is onder andere gevraagd naar de gewenste vorm van het statistisch supplement. Hierbij gaf $67 \%$ van de respondenten aan te kiezen voor zowel een supplement op papier als een supplement op diskette. Een aantal respondenten (16\%) 
gaf aan om het statistisch supplement alleen op diskette uit te brengen. Daartegenover wil $15 \%$ van de respondenten het supplement louter op papier.

\subsection{Gebruiksdoelen}

Om meer inzicht te krijgen in het gebruik van de HBO-Monitor zijn de geënquêteerden gevraagd naar de gebruiksdoeleinden van het landelijk rapport en het statistisch supplement. Daarbij is een onderverdeling gemaakt tussen het landelijk rapport en het statistisch supplement. Het is immers mogelijk om beide onderdelen voor verschillende doeleinden aan te wenden. Daarnaast is het mogelijk dat men één van beide onderdelen niet of slechts in beperkte mate heeft gebruikt. Tabel 3 geeft de verschillende gebruiksdoeleinden weer.

Uit de enquête blijkt dat vrijwel alle respondenten het rapport en de statistische bijlage voor minimaal één van de mogelijke doeleinden gebruikt. Van alle respondenten heeft $7 \%$ geen gebruik gemaakt van het rapport, $9 \%$ van het statistisch supplement, terwijl $1 \%$ noch het rapport noch het statistisch supplement heeft gebruikt. Hierbij dient te worden opgemerkt dat dit wellicht een onderschatting is aangezien afnemers die het rapport dan wel het statistisch supplement niet of weinig gebruikt hebben er ook minder belang aan hechten om aan het gebruikersonderzoek deel te nemen.

Tabel 3

Gebruiksdoeleinden van de HBO-Monitor*

Landelijk Statistisch

rapport supplement

Geen gebruik van gemaakt

Algemene kennisneming van de arbeidsmarktpositie van HBO'ers

Kwaliteitszorg

Onderwijsbeleid

Eigen onderzoek

Studie- en beroepskeuzevoorlichting

Arbeidsmarktbeleid

Andersoortige voorlichting

Scholingsbeleid

Arbeidsbemiddeling

Overige doeleinden

$\begin{array}{rr}7 \% & 9 \% \\ 67 \% & 51 \% \\ 55 \% & 50 \% \\ 41 \% & 44 \% \\ 29 \% & 41 \% \\ 32 \% & 38 \% \\ 23 \% & 22 \% \\ 9 \% & 9 \% \\ 9 \% & 9 \% \\ 3 \% & 3 \% \\ 1 \% & 1 \%\end{array}$

* meerdere antwoorden mogelijk

Zowel het rapport als het statistisch supplement wordt door tenminste de helft van de respondenten gebruikt voor algemene kennisneming van de arbeidsmarktpositie en in het kader van de kwaliteitszorg. Een kwart tot de helft gebruikt zowel het rapport als het statistisch supplement ten behoeve van het onderwijsbeleid, studie- en beroepskeuzevoorlichting, alsmede voor eigen onderzoeksdoeleinden. 
Ten aanzien van enkele gebruiksdoelen manifesteren zich verschillen tussen het rapport en het statistisch supplement. Zo wordt het statistisch supplement relatief vaker gebruikt voor onderzoeksdoeleinden en het rapport voor algemene kennisneming van de arbeidsmarktpositie van hbo'ers.

Hogescholen gebruiken het rapport (24\% versus $71 \%$ ) en het statistisch supplement (33\% versus $100 \%$ ) significant minder vaak voor eigen onderzoek dan andere gebruikers. Een verder significant verschil tussen beide groepen gebruikers betreft de bevinding dat hogescholen het rapport en het statistisch supplement vaak gebruiken ten behoeve van de kwaliteitszorg (rapport 61\%, statistisch supplement 57\%) en voor studie- en beroepskeuzevoorlichting (rapport 36\%, statistisch supplement 43\%), terwijl niemand van de andere gebruikers het rapport en het statistisch supplement voor deze doeleinden gebruikt.

Tabel 4

Redenen voor niet gebruiken

Landelijk rapport
Statistisch supplement

De publicatie was niet relevant

Vanwege het te wetenschappelijk karakter

Vanwege te vage en abstracte gegevens

Vanwege een overdaad aan cijfers

Overige redenen

$\begin{array}{ll}4 & 2 \\ 0 & 1 \\ 1 & 1 \\ 0 & 1 \\ 0 & 1\end{array}$

In tabel 4 is het aantal respondenten aangegeven dat geen gebruik maakt van de publicatie, uitgesplitst naar de reden om geen gebruik te maken van de publicatie. Zoals gezegd betreft het hier een zeer gering aantal respondenten. De meest genoemde reden om voor bepaalde doelen geen gebruik te maken van de publicatie is omdat deze voor de desbetreffende persoon niet relevant blijken te zijn.

\subsection{Gebruikswaarde}

Om een indicatie te krijgen van de waarde die de publicatie heeft voor de verschillende doeleinden, is aan de afnemers gevraagd om per opgegeven doel aan te geven in welke mate het rapport respectievelijk statistisch supplement hiervoor te gebruiken is. Daarbij kan worden opgemerkt dat ook respondenten die géén gebruik hebben gemaakt van het rapport en/of statistisch supplement voor het desbetreffend doel, wel degelijk een oordeel kunnen vellen over de bruikbaarheid. Immers, het kan zo zijn dat een slechte bruikbaarheid het daadwerkelijk gebruik door de respondent in de weg staat.

\section{Gebruikswaarde rapport}

De respondenten beoordelen het landelijk rapport het meest positief op basis van de bruikbaarheid voor de algemene kennisneming van de arbeidsmarktpositie van hbo'ers 
(tabel 5). Indien we bovenstaande tabel combineren met tabel 3 valt op dat de vijf meest gebruikte doeleinden, namelijk algemene kennisneming van de arbeidsmarktpositie van hbo'ers, kwaliteitszorg, onderwijsbeleid, studie- en beroepskeuzevoorlichting en onderzoek ook qua waardering het hoogst scoren. Ze vallen allemaal binnen de categorie goed en redelijk. Daartegenover staat dat de minst gebruikte doeleinden, namelijk scholingsbeleid en arbeidsbemiddeling het hoogst scoren in de categorie niet van toepassing (N.V.T.). Daarmee is aangetoond dat de respondenten die het landelijk rapport voor een bepaald doel niet gebruiken, als reden daarvoor geen slechte bruikbaarheid noemen maar als reden geven dat het desbetreffende doel voor hen niet relevant is. Ten aanzien van drie gebruiksdoelen van het rapport manifesteren zich significante verschillen tussen hogescholen en overige gebruikers. Voor laatstgenoemde gebruikers zijn de gebruiksdoelen kwaliteitszorg $(100 \%$ versus $10 \%)$, onderwijsbeleid (71\% versus $15 \%)$ en studie- en beroepskeuzevoorlichting (100\% versus $29 \%$ ) vaker niet van toepassing dan voor hogescholen.

Tabel 5

Bruikbaarheid van het landelijk rapport

\begin{tabular}{lrrrr}
\hline & $\begin{array}{r}\text { Slecht } \\
\%\end{array}$ & $\begin{array}{r}\text { Redelijk } \\
\%\end{array}$ & $\begin{array}{r}\text { Goed } \\
\%\end{array}$ & $\begin{array}{r}\text { N.V.T } \\
\%\end{array}$ \\
& & & & \\
\hline Algemene kennisneming arbeidsmarktpositie HBO'ers & 0 & 30 & 62 & 8 \\
Kwaliteitszorg & 7 & 37 & 39 & 18 \\
Onderwijsbeleid & 4 & 48 & 25 & 23 \\
Eigen onderzoek & 2 & 41 & 25 & 33 \\
Studie- en beroepskeuzevoorlichting & 0 & 30 & 34 & 36 \\
Arbeidsmarktbeleid & 5 & 20 & 30 & 45 \\
Andersoortige voorlichting & 2 & 14 & 26 & 58 \\
Scholingsbeleid & 5 & 29 & 12 & 54 \\
Arbeidsbemiddeling & 11 & 11 & 5 & 74 \\
Overige doeleinden & 0 & 5 & 5 & 90 \\
& & & & \\
\hline
\end{tabular}

Gebruikswaarde statistisch supplement

Evenals voor het landelijk rapport is er voor het statistisch supplement een aparte vraag ingevoegd die de bruikbaarheid van het statistisch supplement probeert te achterhalen. Ook hier is er voor gekozen om dit te doen aan de hand van het toekennen van een waardering voor de verschillende gebruiksdoeleinden. In tabel 6 worden de percentages gepresenteerd die aangeven in welke mate het statistisch supplement bruikbaar is voor het desbetreffende gebruiksdoel. Uit tabel 6 blijkt dat de algemene kennisneming van de arbeidsmarktpositie ook voor het statistisch supplement het hoogst scoort. Daarna volgt het eigen onderzoek en het onderwijsbeleid. Wellicht dat de uitgebreide en gedetailleerde informatie uit het statistisch supplement de bruikbaarheid voor met name eigen onderzoek bevordert.

Indien net als bij het landelijk rapport bovenstaande tabel wordt vergeleken met tabel 3 dan valt op dat de vier meest voorkomende gebruiksdoelen, namelijk de algemene kennisneming van de arbeidsmarktpositie van hbo'ers, eigen onderzoek, kwaliteitszorg en onderwijsbeleid 
het hoogst scoren op bruikbaarheid. Bij de analyse komt eveneens naar voren dat de minst voorkomende gebruiksdoelen als scholings- en arbeidsmarktbeleid, arbeidsbemiddeling en andersoortige voorlichting het hoogst scoren in de categorie niet van toepassing. Ook bij het statistisch supplement vinden we dus dat de respondenten die geen gebruik maken van de informatie voor een bepaald doel, als reden daarvoor geen slechte bruikbaarheid noemen maar als reden geven dat het desbetreffende doel voor hen niet relevant is. Evenals bij het rapport manifesteren zich bij het statistisch supplement ten aanzien van drie gebruiksdoelen significante verschillen tussen hogescholen en overige gebruikers. Voor laatstgenoemde gebruikers zijn de gebruiksdoelen kwaliteitszorg (100\% versus $10 \%)$, onderwijsbeleid $(75 \%$ versus $20 \%$ ) en studie- en beroepskeuzevoorlichting (100\% versus $27 \%)$ vaker niet van toepassing dan voor hogescholen.

Tabel 6

Bruikbaarheid van het statistisch supplement

\begin{tabular}{|c|c|c|c|c|}
\hline & $\begin{array}{r}\text { Slecht } \\
\%\end{array}$ & $\begin{array}{r}\text { Redelijk } \\
\%\end{array}$ & $\begin{array}{r}\text { Goed } \\
\%\end{array}$ & $\begin{array}{r}\text { N.V.T } \\
\%\end{array}$ \\
\hline Algemene kennisneming arbeidsmarktpositie HBO'ers & 2 & 27 & 59 & 12 \\
\hline Kwaliteitszorg & 9 & 33 & 39 & 19 \\
\hline Onderwijsbeleid & 7 & 33 & 32 & 28 \\
\hline Eigen onderzoek & 2 & 29 & 44 & 25 \\
\hline Studie- en beroepskeuzevoorlichting & 2 & 22 & 40 & 36 \\
\hline Arbeidsmarktbeleid & 5 & 23 & 28 & 44 \\
\hline Andersoortige voorlichting & 2 & 13 & 29 & 56 \\
\hline Scholingsbeleid & 5 & 29 & 12 & 55 \\
\hline Arbeidsbemiddeling & 10 & 10 & 5 & 75 \\
\hline Overige doeleinden & 0 & 5 & 5 & 91 \\
\hline
\end{tabular}

\section{Grafiek 1}

Bruikbaarheid (\%)

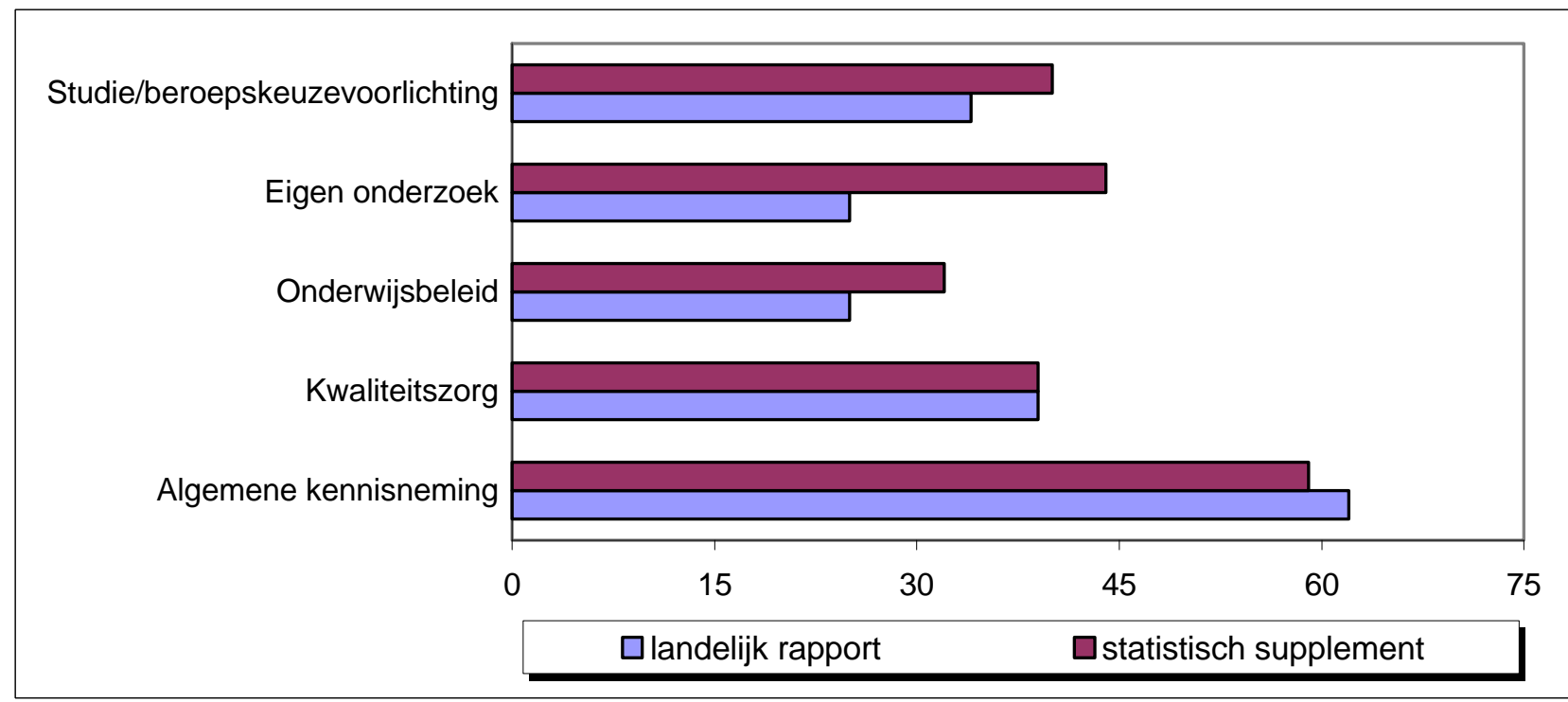


In grafiek 1 is nogmaals de bruikbaarheid weergegeven van het landelijk rapport en het statistisch supplement. De percentages uit de categorie goed zijn afgezet tegen de vijf meest gebruikte doeleinden. Het landelijk rapport blijkt voor de respondenten beter bruikbaar voor de algemene kennisneming van de arbeidsmarktpositie dan het statistisch supplement.

Het statistisch supplement is beter bruikbaar voor studie- en beroepskeuzevoorlichting, eigen onderzoek, en het onderwijsbeleid. Kwaliteitszorg blijkt gelijk te worden beoordeeld.

\subsection{Gebruikersbehoeften}

Naast vragen met betrekking tot de gebruikswaarde van de HBO-Monitor is in de vragenlijst een aantal vragen opgenomen waarbij een algemeen oordeel werd gevraagd over de inhoud en de presentatie van de HBO-Monitor. Op de eerste plaats werd gevraagd of het rapport een beschrijvend of een analytisch karakter moet hebben.

Tabel 7

Gewenste karakter van het landelijk rapport

Vooral beschrijvend

Vooral analytisch

$48 \%$

Totaal n (=100\%)

Zoals blijkt uit tabel 7 zijn de respondenten vrijwel gelijk verdeeld over beide beweringen. Overigens heeft $9 \%$ van de geënquêteerden deze vraag opengelaten omdat ze van mening zijn dat het rapport beide kenmerken dient te hebben of omdat zij aangaven geen antwoord te kunnen geven op deze vraag.

Op de vraag of het wenselijk is dat de totaalcijfers in het statistisch supplement worden uitgesplitst in cijfers voor voltijd en deeltijd antwoordde vrijwel iedereen bevestigend ( $84 \%$ ). Als kanttekening werd daarbij geplaatst dat het in de toekomst wellicht wenselijk zou zijn om ook een aparte categorie duaal onderwijs in te voegen.

Aan de respondenten is gevraagd of men informatie mist in het statistisch supplement, en zo ja, welke informatie men dan mist. Gebleken is dat de meeste respondenten (78\%) geen informatie missen. Hierbij is gebleken dat hogescholen significant vaker (87\% versus $14 \%$ ) geen informatie missen dan overige gebruikers. Voor de resterende $22 \%$ van de respondenten die wel informatie missen in het statistisch supplement $(n=24)$, staat in tabel 8 weergegeven om welke informatie het gaat. De betreffende vraag was een open vraag waardoor de respondenten een uitgebreid aantal verschillende antwoorden gaven, veertien in totaal. In tabel 8 staan de genoemde items opgesomd waarbij het aantal respondenten wordt weergegeven dat betreffend item heeft genoemd.

Overigens bevat het statistisch supplement volgens $98 \%$ van de respondenten geen overbodige informatie. 
Gemiste informatie in statistisch supplement

Reden waarom studenten voor andere opleiding kiezen

Trends

Gegevens per hogeschool

Accreditatie-eisen alumni

Bruikbare informatie KNO

Rendementscijfers

Buitenlandervaring

Uitsplitsing mannen/vrouwen

Aantal studenten

Werkgeversoordelen over opleidingen

Oordeel over beroepsloopbaan
2 hogescholen
2 hogescholen
1 hogeschool* $^{*}$
1 hogeschool
1 hogeschool
1 overige gebruiker
1 overige gebruiker
1 overige gebruiker
1 overige gebruiker
1 overige gebruiker
1 hogeschool

${ }^{*}$ Eveneens genoemd door 1 overige gebruiker

\subsection{Gebruikersoordeel}

Het statistisch supplement is bij de HBO-Monitor 1999 voor het eerst op diskette aangeleverd. In de vragenlijst is dan ook specifiek gevraagd naar de gebruiksvriendelijkheid en de overzichtelijkheid van het geautomatiseerd statistisch supplement. De respondenten maakten hun oordeel kenbaar door een afgerond rapportcijfer te geven van 1 tot en met 10 . Naast een oordeel over het statistisch supplement is eveneens een eindoordeel gevraagd over de HBO-Monitor in het algemeen. Door middel van een afgerond rapportcijfer gaven de respondenten hun mening over het nut, de betrouwbaarheid en de prijs-kwaliteitverhouding van de HBO-Monitor. In tabel 9 staan de scores gepresenteerd voor de verschillende beoordelingscriteria.

Tabel 9

Gemiddelde scores (rapportcijfers)

Score Std. aantal

Gebruiksvriendelijkheid geautomatiseerd statistisch supplement

$\begin{array}{lll}6,9 & 0,9 & 43\end{array}$

Overzichtelijkheid geautomatiseerd statistisch supplement

$6,9 \quad 0,6$

Nut van de publicatie HBO-Monitor

Betrouwbaarheid van de publicatie

Prijs-kwaliteitverhouding van de publicatie

$6,6 \quad 1,0$

Uit de tabel blijkt dat het nut van de HBO-Monitor het hoogst wordt gewaardeerd met een score van 7,4 punten. Daarna volgt de score van 7,0 voor de betrouwbaarheid van de 
publicatie. Deze score heeft overigens de hoogste standaarddeviatie die wordt veroorzaakt door de vrij grote spreiding van de rapportcijfers. De rapportcijfers variëren van 4 tot en met 10. Het overgrote deel (67\%) geeft echter een 7 of een 8 voor de betrouwbaarheid. Significante verschillen in waardering tussen de hogescholen en de overige gebruikers manifesteren zich ten aanzien van de gebruiksvriendelijkheid van het statistisch supplement en de betrouwbaarheid van de publicatie. De overige gebruikers waarderen zowel de gebruiksvriendelijkheid van het statistisch supplement $(7,4$ versus 6,7$)$ als de betrouwbaarheid van de publicatie $(8,3$ versus 6,9$)$ hoger dan de hogescholen.

In grafiek 2 is aangegeven hoeveel procent van de respondenten de HBO-Monitor een voldoende geeft en hoeveel procent van de respondenten een onvoldoende heeft gegeven. Uit de grafiek blijkt dat de betrouwbaarheid het grootste percentage onvoldoendes heeft gekregen. Bij een verdere analyse van de cijfers blijkt dat $78 \%$ van de respondenten die een onvoldoende heeft gegeven voor de betrouwbaarheid, dit wijten aan de soms zeer kleine aantallen afgestudeerden per opleidingsrichting. Met name bij de kleine opleidingen zoals in de kunstensector zijn bepaalde cijfers gebaseerd op slechts enkele respondenten. De gebruikers geven aan dat ze met dergelijke cijfers moeilijk kunnen werken. Het tast in hun ogen niet alleen de betrouwbaarheid aan van de Monitor maar ook het nut en daarmee dus ook de prijs-kwaliteitverhouding.

Tenslotte werd de ondervraagden de mogelijkheid geboden opmerkingen te maken ten aanzien van de HBO-Monitor en/of de vragenlijst. Hierbij kwam naar voren dat een enkele respondent het bezwaarlijk vond dat de gegevens in het landelijk rapport anders worden gepresenteerd dan in de instellingsrapportage. Dit leidt volgens hem tot onnodig veel puzzelwerk. Daarnaast zou het nut en de betrouwbaarheid van de publicatie kunnen worden vergroot indien er regionale gegevens beschikbaar zouden komen en nog meer hogescholen/opleidingen in de HBO-Monitor zouden participeren1.

Grafiek 2

Waardering

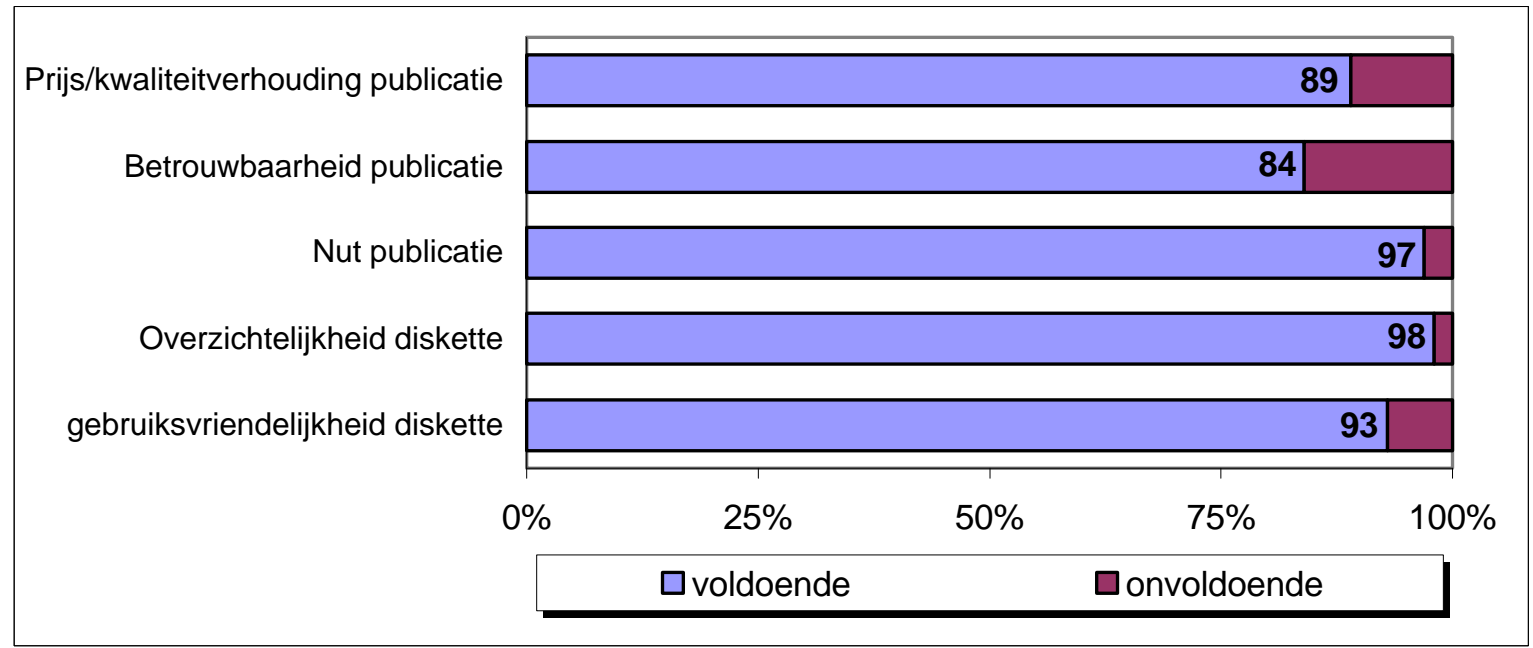

1. Thans neemt $85 \%$ van de hogescholen deel aan de HBO-Monitor. 


\section{Onderzoeksresultaten instellingsrapportages}

\subsection{Onderzoeksvragen}

In dit hoofdstuk zullen de resultaten worden gepresenteerd van het gebruikersonderzoek ten behoeve van de Instellingsrapportage HBO-Monitor 1999. Evenals bij de onderzoeksresultaten van de landelijke rapportage zal ook hier eerst ingegaan worden op de centraal geformuleerde onderzoeksvragen. De onderzoeksvragen voor de instellingsrapportage zijn:

- Wie zijn de gebruikers van de HBO-Monitor en in welke sectoren zijn ze werkzaam?

- Welke waardering krijgen de verschillende onderdelen van de instellingsrapportage voor de bruikbaarheid, overzichtelijkheid en de volledigheid?

- Voor welk soort doeleinden gebruikt men de instellingsrapportage?

- Welke waardering geeft men aan de gebruikswaarde van de instellingsrapportage in relatie tot de beschreven doeleinden?

- Bestaat er bij de verschillende gebruikers behoefte aan uitbreiding van de gepresenteerde informatie?

- Wat is het eindoordeel van de verschillende gebruikers met betrekking tot het nut, de betrouwbaarheid en de prijs-kwaliteitverhouding van de instellingsrapportage?

Daarnaast wordt er gevraagd naar de mening met betrekking tot bepaalde specifieke onderwerpen:

- Is de informatie omtrent de mogelijkheid om deel te nemen aan de HBO-Monitor duidelijk en volledig?

- Welke verschijningsdatum van de instellingsrapportage wordt door de gebruikers geprefereerd?

- In welke mate is er sprake van overbodig gepresenteerde informatie?

- In hoeverre zijn hogescholen geï nteresseerd om te participeren in het digitaal discussieforum? (gesloten e-maillijst)

\subsection{Gebruikers}

Uit het adressenbestand van DESAN zijn alle 111 personen geënquêteerd die werkzaam zijn bij verschillende hogescholen. Van die 111 personen waren 62 personen werkzaam bij een centrale dienst van een hogeschool en 49 bij een faculteit van een hogeschool. De respons lag op 36\% waarbij opgemerkt kan worden dat de vragenlijsten zijn verspreid onder de zeven participerende opleidingssectoren van de HBO-Monitor. In tabel 10 wordt een overzicht gegeven van de betreffende sectoren die aan het gebruikersonderzoek hebben meegedaan. Dit zijn de resultaten op een vraag waar meerdere antwoorden mogelijk zijn. Immers, veel respondenten gaven aan de vragenlijst in te vullen voor meerdere sectoren. Tabel 10 laat ook zien dat de meeste vragenlijsten zijn ingevuld voor de opleidingssectoren hoger economisch onderwijs, gevolgd door het hoger pedagogisch onderwijs. 
Tabel 10

Sectoren*

Hoger agrarisch onderwijs

$12 \%$

Hoger pedagogisch onderwijs

$29 \%$

Hoger technisch onderwijs

$17 \%$

Hoger economisch onderwijs

$40 \%$

Hoger gezondheidszorg onderwijs

$17 \%$

Hoger sociaal-agogisch onderwijs

$21 \%$

Kunstonderwijs

$24 \%$

Totaal n (=100\%)

${ }^{*}$ meerdere antwoorden mogelijk

Ook is gekeken naar de status van de geënquêteerden. Welke functie bekleedt hij of zij binnen de hogeschool? In tabel 11 is te zien dat met name kwaliteitszorgmanagers en medewerkers onderwijsbeleid de vragenlijsten hebben ingevuld. Er dient dan ook rekening te worden gehouden met het grote gewicht dat de kwaliteitszorgmanagers leggen in de beoordeling van de instellingsrapportage. Daarnaast bestaat er een sterk verband tussen de status van de geënquêteerden en de genoemde gebruiksdoelen van de instellingsrapportage. Een decaan/studievoorlichter zal immers de rapportage meer gebruiken voor de uitoefening van zijn functie als voorlichter. Een kwaliteitszorgmanager daarentegen is meer geï nteresseerd in de gebruikswaarde ten behoeve van het monitoren van het extern rendement en de evaluatie van het curriculum.

Tabel 11

Functie geënquêteerde

Medewerker centrale dienst hogeschool $\quad 20 \%$

Opleidingscoördinator $\quad 10 \%$

Kwaliteitszorgmanager/medewerker onderwijsbeleid $\quad 39 \%$

Decaan/studievoorlichter $2 \%$

Overig 29\%

Totaal $\mathrm{n}(=100 \%) \quad 41$

De respondenten vanuit het hoger pedagogisch onderwijs zijn met name werkzaam bij de centrale diensten terwijl het overgrote deel van de respondenten uit het hoger economisch onderwijs kwaliteitszorgmanagers zijn. In de categorie overig vallen de vaksectievoorzitters docenten, faculteitsdirecteuren, pr/marketingmedewerkers en communicatiemedewerkers.

De respondenten zijn ook gevraagd een oordeel te vellen over de volledigheid en duidelijkheid van het aanbod om deel te nemen aan de HBO-Monitor. Dit aanbod krijgen ze jaarlijks toegestuurd waarin hen wordt gevraagd om (opnieuw) deel te nemen aan de HBO- 
Monitor. Vrijwel alle respondenten (97\%) gaven aan het aanbod volledig te vinden. Daarnaast vond eveneens $97 \%$ het aanbod duidelijk. Tevens is specifiek gevraagd of het aanbod duidelijk genoeg is met betrekking tot de mogelijkheid voor de hogeschool om instellingsspecifieke vragen te laten opnemen in de enquête. Het antwoord was vrijwel unaniem ja (93\%). Het oordeel over het aanbod is dus duidelijk positief.

In tabel 12 staat een uitgebreide lijst van gebruikers van de instellingsrapportage. Aan de contactpersonen is gevraagd aan te geven wie binnen de betreffende hogeschool gebruik maakt van de HBO-Monitor. Bij deze vraag waren uiteraard meerdere antwoorden mogelijk. Wat opnieuw opvalt is het grote gebruik van de HBO-Monitor door de kwaliteitszorgmanagers en de faculteitsdirecteuren. Maar ook de opleidingscoördinatoren blijken veel gebruik te maken van de HBO-Monitor. Dit is met name toe te schrijven aan de gedetailleerdheid van de instellingsrapportage. De cijfers worden immers niet alleen voor een betreffende hogeschool per sector gepresenteerd maar worden ook uitgesplitst naar verschillende opleidingen. Bovendien bestaat de instellingsrapportage uit verschillende soorten onderdelen die zijn toegespitst op de verschillende gebruikersbehoeften. Een bestuurder maakt wellicht het meest gebruik van het managementrapport terwijl een decaan met name de individuele rapportage interessant zal vinden. Het minst gebruik van de HBOMonitor maken de vaksectievoorzitters en de docenten.

Tabel 12

Gebruikers van de instellingsrapportage

$\begin{array}{lr}\text { Bestuurders centraal niveau } & 60 \% \\ \text { Bestuurders faculteitsniveau } & 81 \% \\ \text { Medewerkers centrale dienst hogeschool } & 48 \% \\ \text { Medewerkers faculteitsdienst } & 31 \% \\ \text { Opleidingscoördinatoren } & 74 \% \\ \text { Kwaliteitszorgmanagers/medewerkers onderwijsbeleid } & 81 \% \\ \text { Decanen/studievoorlichters } & 50 \% \\ \text { Vaksectievoorzitters/docenten } & 17 \% \\ \text { Overig } & 7 \%\end{array}$

\subsection{Gebruiksdoelen en bruikbaarheid}

In een paragraaf van de instellingsrapportage staan de doelen en gebruiksmogelijkheden genoemd van de rapportage. De gebruiksmogelijkheden zijn zeer uitgebreid en hebben betrekking op het kwaliteitszorgbeleid, de pr en voorlichting en het alumnibeleid. In tabel 13 is aan de hand van een percentage aangegeven in welke mate de respondenten gebruik maken van de instellingsrapportage met betrekking tot de betreffende gebruiksmogelijkheden. In de kolom ernaast is te zien hoe het gebruik van de instellingsrapportage wordt gewaardeerd met betrekking tot betreffend gebruiksdoel. Uit de tabel blijkt dat het monitoren van het extern rendement geldt als het meest genoemde gebruiksdoel van de instellingsrapportage. Op de tweede en derde plaats komen de interne voorlichting en het evalueren van het curriculum. Wat dus opvalt is dat het gebruik in het kader van de 
kwaliteitszorg het hoogst scoort. Naast de gebruiksdoelen met betrekking tot de kwaliteitszorg scoort de voorlichting eveneens erg hoog. Liefst $84 \%$ van de respondenten gaf aan de instellingsrapportage te gebruiken voor interne voorlichting. Voor de externe voorlichting ligt dit percentage op $82 \%$. Het minst gebruik maken de respondenten van de instellingsrapportage voor het werven van stageplaatsen en stagebegeleiders $(3 \%=1$ respondent). Het gebruik ten behoeve van een studentvolgsysteem (18\%) scoort net als het loopbaanadviescentrum (9\%) en de bedrijvencontactdagen (14\%) laag. Er moet echter worden opgemerkt dat de meeste respondenten waarschijnlijk beschikken over onvolledige informatie waardoor er geen totaal beeld kan worden geschetst van het gebruik van de instellingsrapportages binnen de gehele hogeschool/faculteit.

De respondenten hebben door middel van een toe te kennen rapportcijfer van 1 tot en met 10 aangegeven in hoeverre zij de instellingsrapportage bruikbaar vinden voor de betreffende doeleinden. Uit de kolom met de scores valt op te maken dat de bruikbaarheid van de instellingsrapportage voldoende tot goed is voor vrijwel alle genoemde items. Alleen de werving van stageplaatsen en stagebegeleiders is een weinig bruikbaar doel te noemen. Het meest blijkt de instellingsrapportage geschikt voor het monitoren van het extern rendement, voorlichting en het organiseren van bedrijvencontactdagen. De respondenten blijken voor deze drie betreffende items in hun waardering ook weinig verdeeld gezien de vrij lage standaarddeviatie.

Tabel 13

Gebruiksdoel en gebruikswaarde

\begin{tabular}{lrrr}
\hline & Gebruik & \multicolumn{2}{c}{ Bruikbaarheid } \\
& & Score & Std. \\
& & & \\
\hline & & 7,0 & 0,94 \\
Monitoren van extern rendement & $89 \%$ & 6,8 & 1,13 \\
Evaluatie van het curriculum & $83 \%$ & 6,1 & 1,62 \\
Gegevens t.b.v. studentvolgsysteem & $18 \%$ & 6,7 & 1,03 \\
Cursusaanbod en contractonderwijs & $53 \%$ & 5,3 & 1,70 \\
Werving stageplaatsen en stagebegeleiders & $3 \%$ & 7,1 & 0,89 \\
Interne voorlichting & $84 \%$ & 7,2 & 0,82 \\
Externe voorlichting & $82 \%$ & 6,6 & 0,92 \\
Cursus loopbaanoriëntatie & $22 \%$ & 6,8 & 1,46 \\
Terugkomdagen & $31 \%$ & 6,6 & 1,27 \\
Bedrijvencontactdagen & $14 \%$ & 6,5 & 0,84 \\
Loopbaanadviescentrum & $9 \%$ & 7,0 & 0,00 \\
Overige doeleinden & $15 \%$ & & \\
\hline
\end{tabular}

\subsection{Waardering onderdelen instellingsrapportage}

Om een beeld te krijgen van de bruikbaarheid, de overzichtelijkheid en de volledigheid van de verschillende onderdelen van de instellingsrapportage worden in de onderstaande tabel 
de scores gepresenteerd voor betreffende onderdelen. De respondenten gaven ook hier weer een waarderingscijfer van 1 tot en met 10 .

De bruikbaarheid van de diskette wordt over het algemeen het laagst gewaardeerd, maar gemiddeld nog altijd met een voldoende. Het managementrapport daarentegen scoort het hoogst op bruikbaarheid en overzichtelijkheid terwijl het statistisch overzicht het hoogst scoort op de volledigheid. De grootste groep gebruikers, de kwaliteitszorgmanagers beoordelen het managementrapport goed. Voor de bruikbaarheid geven ze een 7,4. Daarentegen beoordelen ze de volledigheid iets onder het gemiddelde namelijk met een 7 . Omdat de cijfers variëren tussen de 7 en de 8 is de waardering voor het managementrapport ruim voldoende tot goed. Overigens blijken er geen opvallende verschillen te bestaan tussen de waarderingen door de verschillende sectoren. De rapportage blijkt voor de respondenten uit het kunstenonderwijs even bruikbaar als voor de hogescholen uit de economische sector.

Tabel 14

Gemiddelde scores (rapportcijfers)

\begin{tabular}{lcccccr}
\hline & \multicolumn{2}{c}{ Bruikbaarheid } & \multicolumn{2}{c}{ Overzichtelijkheid } & \multicolumn{2}{c}{ Volledigheid } \\
& Score & Std. & Score & Std. & Score & Std. \\
& & & & & & \\
& 7,4 & 0,82 & 7,5 & 0,71 & 7,3 & 0,90 \\
Managementrapport & 7,2 & 0,76 & 7,1 & 0,80 & 7,5 & 0,77 \\
Statistisch overzicht & 6,9 & 1,23 & 7,1 & 0,99 & 6,7 & 0,04 \\
Individuele rapportage & 6,8 & 1,13 & 7,0 & 1,04 & 7,1 & 0,08 \\
Technische toelichting & 6,2 & 1,57 & 7,1 & 0,92 & 6,6 & 0,30 \\
Toekomstperspectief & 6,1 & 1,58 & 7,1 & 1,07 & 6,7 & 0,03 \\
Diskette & & & & & & \\
\end{tabular}

\subsection{Gebruikersbehoeften}

In de vragenlijst is ruimte geboden om de respondenten hun specifieke gebruikersbehoeften kenbaar te laten maken. Voor elk onderdeel van de instellingsrapportage werd apart gekeken of er informatie werd gemist. Het merendeel (82\%) van de respondenten gaf echter aan geen enkele informatie te missen. Overigens kan worden opgemerkt dat geen enkele respondent hetzelfde item heeft genoemd. Met betrekking tot het managementrapport werden de volgende items genoemd:

- passage over de accreditering;

- categorie duaal onderwijs;

- kort overzicht van de opleidingsscores binnen de hogeschool.

In het statistisch overzicht was volgens drie respondenten eveneens sprake van ontbrekende informatie zoals:

- oordeel over de betekenis en inrichting van stages;

- categorie duaal onderwijs; 
- trends over enkele jaren.

Met betrekking tot de individuele rapportage bestaat er behoefte aan informatie die antwoord kan geven op de vraag of sommige afgestudeerden nog contact willen houden met de school.

Zoals gezegd beperkt het monitoren van HBO-afgestudeerden zich tot anderhalf jaar na het afstuderen. $\mathrm{Om}$ in de toekomst een meer volledig beeld te krijgen van de arbeidsmarktpositie van HBO'ers is het wellicht een optie deze meting uit te breiden met een follow-up meting. Dat wil zeggen dat afgestudeerden voor een langere periode worden gevolgd. Aan de geënquêteerde hogescholen is gevraagd of zij interesse tonen voor dit initiatief. Van het totaal aantal respondenten gaf $35 \%$ aan dat hun hogeschool positief tegenover een dergelijke loopbaanmeting staat. Uiteraard kan bij gebrek aan interesse moeilijk landelijk dekkende cijfers worden gepubliceerd. Daarom is de betreffende vraag opnieuw gesteld met als opmerking dat deelname zonder landelijk beschikbare cijfers tot de mogelijkheden behoorde. Op deze vraag antwoordde $26 \%$ bevestigend. Zij gaven aan ook deel te willen nemen aan een loopbaanmeting ondanks het ontbreken van landelijke cijfers.

\subsection{Gebruikersoordeel}

In tabel 15 zijn enkele opmerkingen opgenomen waarbij de ondervraagden dienden aan te geven of ze het er mee eens waren of niet. De respondenten zijn over het algemeen vrij lovend over de rapportage zelf alsmede de organisatie daaromtrent. Zo vindt het merendeel dat de instellingsrapportage voldoende informatie verstrekt. Daarbij kan worden opgemerkt dat slechts twee respondenten aangeven dat de instellingsrapportage overbodige informatie bevat. Een respondent noemt de gehele individuele rapportage overbodig terwijl een ander de vraag met betrekking tot de plaats van de werkzaamheden als niet-relevant beoordeelt.

Tabel 15

Oordelen gebruikers over

$\begin{array}{cc}\text { Mee } & \text { Mee } \\ \text { oneens } & \text { eens }\end{array}$

Rapportage verstrekt voldoende informatie

$18 \% \quad 82 \%$

Rapportage verstrekt overbodige informatie

$94 \% \quad 6 \%$

Gedurende het monitoren moet er tussentijdse informatie worden verstrekt $\quad 90 \% \quad 10 \%$

Indeling van de totaalcijfers voltijd/deeltijd is duidelijk

$11 \% \quad 89 \%$

Opzet van de kwaliteitsscores in het managementrapport is duidelijk

$7 \% \quad 92 \%$

Managementrapportage moet als apart verslag worden aangeboden2

$63 \% \quad 17 \%$

2. Bij deze vraag konden respondenten kiezen voor de antwoordcategorie geen mening. $20 \%$ Van de respondenten gaf aan geen mening te hebben. 
Verder werd een oordeel gevraagd met betrekking tot de datum waarop de instellingsrapportage uiterlijk dient te verschijnen. De maanden mei (31\%) en juni (29\%) worden het vaakst genoemd als maanden waarin de instellingsrapportage uiterlijk beschikbaar moet zijn. In grafiek 3 zijn de percentages gecumuleerd weergegeven. Daarbij is uitgegaan van de veronderstelling dat degenen die een bepaalde maand hebben genoemd als uiterlijke verschijningsdatum voorafgaande maanden hoger zullen waarderen of even hoog zullen waarderen. Uit de grafiek valt af te leiden dat ongeveer de helft (46\%) van de respondenten juni als uiterlijke maand van verschijning acceptabel vindt.

Wordt de instellingsrapportage in de maand mei uitgebracht, dan wordt tegemoet gekomen aan het overgrote deel (77\%) van de respondenten. Uiteraard kan daarbij worden opgemerkt dat over het algemeen de meeste afnemers geï nteresseerd zijn in een eerdere levering; de vraag daarbij is alleen of dat ook haalbaar is.

\section{Grafiek 3}

Gewenste verschijningsmaand

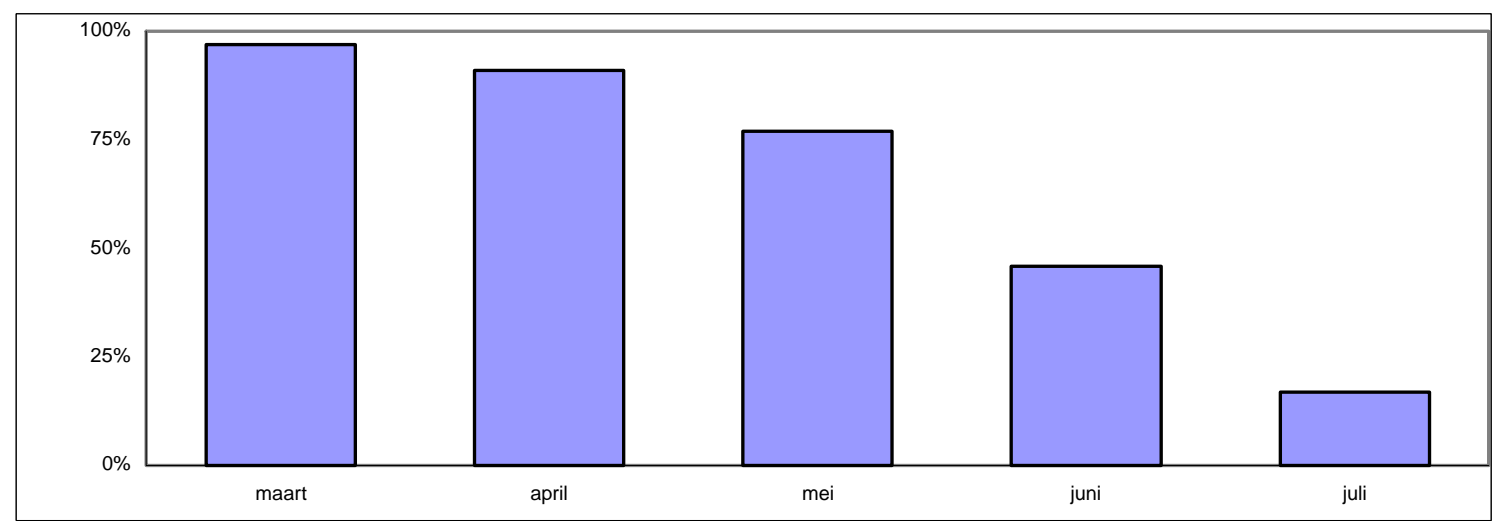

Evenals bij het gebruikersonderzoek voor het landelijk rapport is een eindoordeel gevraagd met betrekking tot de betrouwbaarheid en de prijs/kwaliteitsverhouding van de instellingsrapportage HBO-Monitor 1999. In onderstaande tabel zijn de resultaten gepresenteerd. Uit tabel 16 blijkt dat de instellingsrapportage goed scoort op betrouwbaarheid. Ook de prijs/kwaliteitsverhouding krijgt een ruime voldoende met een score van 6,7 . Voor beide scores geldt wel dat de standaarddeviatie aan de hoge kant is. Overigens gaf slechts $7 \%$ van de respondenten aan de betrouwbaarheid van de instellingsrapportage HBOMonitor onvoldoende te vinden, terwijl $12 \%$ de prijs-kwaliteitverhouding onvoldoende vond.

Tabel 16

Gemiddelde scores (rapportcijfers) 


\section{Systematische evaluatie}

\subsection{Huidige opzet}

Het ontbreken van feedback bij de opstellers van de rapportages blijkt een probleem te zijn om het gebruik van het landelijk rapport (en het statistisch supplement) alsmede de instellingsrapportage te kunnen inschatten. In figuur 1 wordt de huidige opzet van de HBOMonitor weergegeven. Het proces van dataverzameling begint jaarlijks vanaf de maand september. Bij de HBO-Monitor 1999 zijn daarbij circa 38.600 afgestudeerden aangeschreven. De verwerking van de gegevens gebeurt door het marktonderzoeksbureau DESAN. De instellingsrapportages komen in de maanden april/mei beschikbaar, de landelijke rapportage in juni. Wat opvalt in figuur 1 is het ontbreken van een systematische terugkoppeling door de gebruikers van de rapportages. In paragraaf 2 van dit hoofdstuk wordt een alternatief model gepresenteerd dat wel voorziet in een systematische evaluatie.

Figuur 1

Huidige opzet HBO-Monitor

\begin{tabular}{|ll|}
\hline Dataverzameling & DESAN \\
\hline Rapportage & $\begin{array}{l}\text { Instellingsrapport: DESAN en ROA } \\
\text { Landelijk rapport: HBO-raad en ROA }\end{array}$ \\
\hline Gebruik & Hogeschool/Faculteit \\
\hline
\end{tabular}

\subsection{Nieuwe opzet}

In figuur 1 was te zien dat de HBO-Monitor geen evaluatiemechanisme kent. Het feit dat de deelnemende hogescholen/faculteiten de rapportage jaarlijks afnemen maakte de uitvoering van dit evaluatieonderzoek wenselijk. De opstellers van de rapportages, te weten; ROA, DESAN en HBO-raad streven echter naar een periodiek terugkerende evaluatie voor de HBO-Monitor. Onderstaande figuur laat de wenselijke situatie zien die de opstellers nastreven. Het model kenmerkt zich door een terugkoppelingsmechanisme richting de opstellers van de rapportages.

Het uitgevoerde evaluatieonderzoek kan dienen als input voor het groepsoverleg en het digitaal discussieforum. Dit digitaal discussieforum zal worden opgezet door middel van het aanleggen van een gesloten e-maillijst. De onderzoeksresultaten zoals die in voorgaande hoofdstukken zijn behandeld kunnen breed worden bediscussieerd door de klankbordgroep HBO-Monitor en zullen eveneens worden teruggekoppeld richting de hogescholen die aangaven deel te willen nemen aan het digitaal discussieforum. Bij de systematische evaluatie van de HBO-Monitor is het dus de bedoeling dat er in tegenstelling tot de huidige situatie een sturingsmechanisme wordt gecreëerd dat alle betrokken partijen helpt bij het bewaken van de kwaliteit van hun eigen werk. Daarentegen zullen ook de hogescholen/ faculteiten profijt hebben bij deze opzet. 
Figuur 2

Systematische evaluatie HBO-Monitor

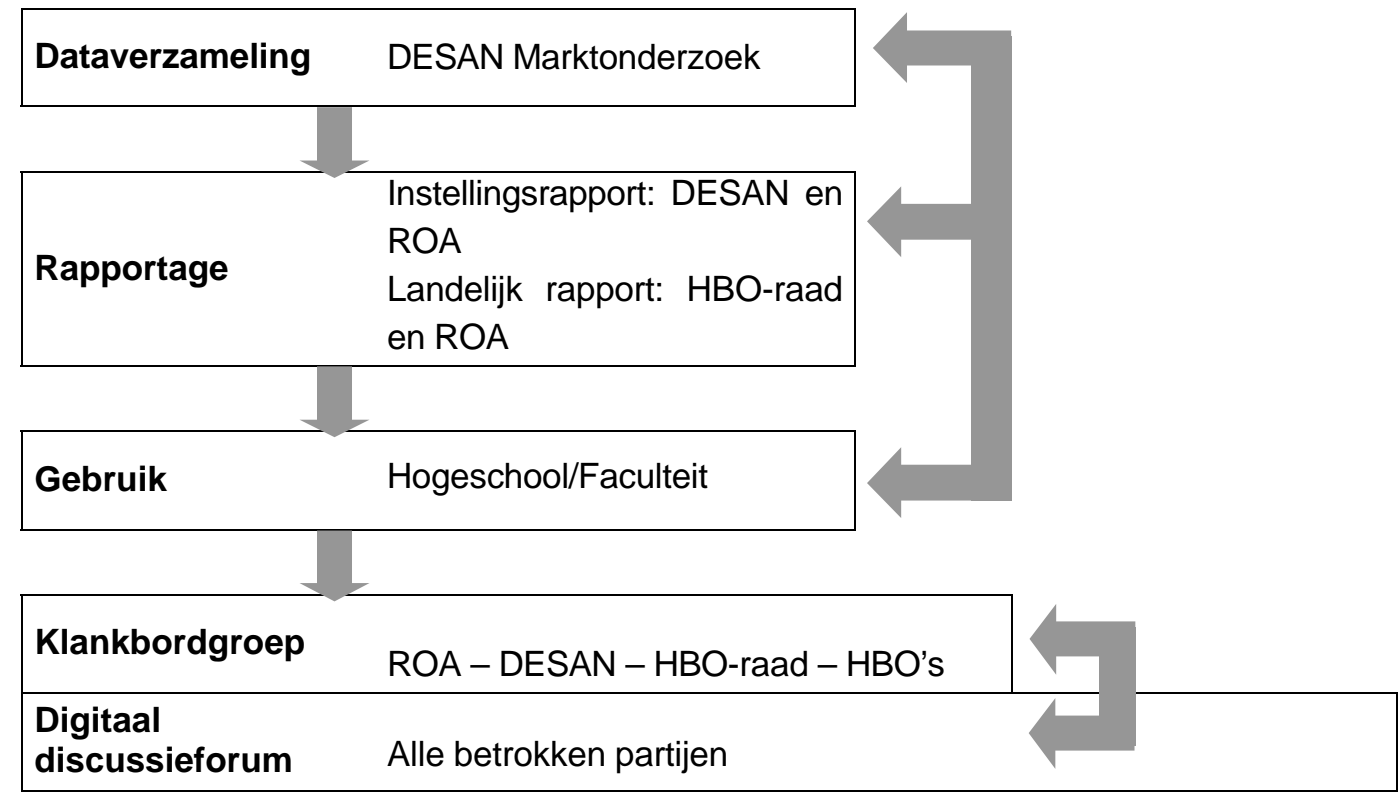

De hogescholen zijn niet alleen gegarandeerd van inspraak maar ook in staat om ervaringen uit te wisselen met collega's. Het is de bedoeling dat de klankbordgroep ongeveer één maal per jaar bijeen komt om in de komende jaren de evaluatie van de HBO-Monitor voort te zetten. De input voor die klankbordgroep wordt onder andere gevormd door de discussies die plaatshebben in het digitaal discussieforum. Daarbij is het vanzelfsprekend dat er richting de participanten in deze gesloten e-maillijst terugkoppeling plaatsvindt. Er ontstaat dus een wisselwerking tussen alle actoren van de HBO-Monitor waardoor de verantwoordelijkheid voor de kwaliteit van de HBO-Monitor breed wordt gedragen.

In de vragenlijst Instellingsrapportage HBO-Monitor 1999 is stilgestaan bij het idee van het oprichten van een klankbordgroep HBO-Monitor en het digitaal discussieforum (gesloten emaillijst). Allereerst is gevraagd of de geënquêteerde hogeschool bereid is te participeren in het nog op te richten digitaal discussieforum. Op deze vraag antwoordde maar liefst $74 \%$ bevestigend. Het gaat hier om in totaal 31 hogescholen/faculteiten die hun e-mailadres ter beschikking hebben gesteld voor informatie en discussie omtrent de instellingsrapportage. Vervolgens is aan de geënquêteerden gevraagd of zij het voorstel voor het oprichten van de klankbordgroep en het digitaal discussieforum voldoende achten voor een brede kwaliteitszorg van de instellingsrapportage HBO-Monitor. Vrijwel iedereen (95\%) achtte het voorstel voldoende.

\section{Conclusie}

Landelijke rapportage en het statistisch supplement

Via de HBO-raad hebben 218 personen de publicatie ontvangen. Hiervan blijkt $73 \%$ een hogeschool te zijn. Het aandeel van de hogescholen in het totaal aantal respondenten 
bedraagt $89 \%$. Door de relatief nauwe betrokkenheid van de hogescholen bij de opstelling van de HBO-Monitor kan de oververtegenwoordiging van deze groep in de steekproef worden verklaard. De afnemers van het landelijk rapport (inclusief het statistisch supplement) vormen een vaste groep. Dit kan worden geconcludeerd uit de wijze van kennisneming. Immers, $73 \%$ van de respondenten geeft aan de HBO-Monitor te kennen van eerder uitgebrachte rapportages.

Algemene kennisneming van de arbeidsmarktpositie van hbo'ers, kwaliteitszorg, onderwijsbeleid en studie- en beroepskeuzevoorlichting zijn veel genoemde gebruiksdoelen. Slechts $16 \%$ van de respondenten geeft aan één van de onderdelen (of beide) van de landelijke HBO-Monitor niet te gebruiken. De mate van bruikbaarheid wordt voor de meest gebruikte doeleinden als goed/redelijk gekwalificeerd. Het landelijk rapport scoort het beste voor de algemene kennisneming van de arbeidsmarktpositie van hbo'ers. Daarentegen scoort het statistisch supplement het hoogst voor de bruikbaarheid voor onderzoeksdoeleinden. Dit kan wellicht worden verklaard uit de uitgebreide en gedetailleerde cijfers.

Met betrekking tot de specifieke gebruikersbehoeften ten aanzien van het landelijk rapport en het statistisch supplement kan worden opgemerkt dat het rapport zowel beschrijvende als analytische informatie dient op te leveren. Tot slot kan worden geconcludeerd dat de respondenten overwegend positief denken over de landelijke rapportage HBO-Monitor. Zo beoordelen zij het nut van de publicatie met een gemiddeld rapportcijfer van een 7,4 . De betrouwbaarheid en de prijs-kwaliteitverhouding krijgen respectievelijk een 7,0 en een 6,6 .

\section{Instellingsrapportage}

Kwaliteitszorgmanagers, faculteitsdirecteuren en opleidingscoördinatoren vormen de grootste groepen van respondenten. De gebruikersgroep van de instellingsrapportages vormt zich vanaf centraal niveau tot en met faculteits- en opleidingsniveau. Daarin zijn de faculteitsbestuurders en de kwaliteitszorgmanagers de grootste groep.

De instellingsrapportage wordt het meest gebruikt voor doeleinden met betrekking tot de kwaliteitszorg en voorlichting. Het monitoren van het extern rendement (89\%) de evaluatie van het curriculum (83\%) interne voorlichting (84\%) en de externe voorlichting (82\%) scoren qua gebruikswaarde het hoogst. De instellingsrapportage wordt echter het minst gebruikt voor een loopbaanadviescentrum, bedrijvencontactdagen en de werving van stageplaatsen en/of stagebegeleiders. Dit wil niet zeggen dat de bruikbaarheid van de instellingsrapportage slecht beoordeeld wordt met betrekking tot deze minst gebruikte doeleinden. De meeste respondenten geven aan dat betreffend gebruiksdoel voor hen niet van toepassing is. Tenslotte kan over de gebruikswaarde geconcludeerd worden dat deze hoog scoort met betrekking tot de verschillende onderdelen van de rapportage, te weten het managementrapport, het statistisch overzicht, de individuele rapportage, de technische toelichting, het toekomstperspectief en de bijgeleverde diskette. Met name het managementrapport scoort op bruikbaarheid $(7,4)$ overzichtelijkheid $(7,5)$ en volledigheid $(7,3)$ ruim voldoende. 
Daarnaast is $35 \%$ van de geënquêteerde hogescholen geï nteresseerd in een follow-up meting (loopbaanmeting) van afgestudeerden. Verder blijkt dat de meeste respondenten vinden dat de instellingsrapportage uiterlijk in mei/juni uitgebracht moet worden. Het eindoordeel met betrekking tot de betrouwbaarheid en de prijs-kwaliteitverhouding scoort (ruim) voldoende met respectievelijk een 7,1 en een 6,7 .

\section{Systematische evaluatie}

Om een mechanisme te creëren dat periodieke evaluatie mogelijk maakt is een voorstel gedaan om een klankbordgroep en een digitaal discussieforum op te richten ten behoeve van de HBO-Monitor. Liefst $95 \%$ van de respondenten steunt het voorstel. Daarnaast heeft $74 \%$ van de respondenten aangegeven te willen participeren in het digitaal discussieforum dat wordt vormgegeven aan de hand van een gesloten e-maillijst. 
Bijlage 1 Vragenlijst landelijk rapport 
Bijlage 2 Vragenlijst instellingsrapportages 
